Editorial

\title{
Narrating Global Order and Disorder
}

\author{
Matthew Levinger ${ }^{1, *}$ and Laura Roselle ${ }^{2}$ \\ ${ }^{1}$ Elliott School of International Affairs, George Washington University, Washington, DC 20052, USA; \\ E-Mail: mlevinger@email.gwu.edu \\ 2 Department of Political Science, Elon University, Elon, NC 27249, USA; E-Mail: Iroselle@elon.edu \\ * Corresponding author
}

Submitted: 25 September 2017 | Published: 29 September 2017

\begin{abstract}
This thematic issue addresses how strategic narratives affect international order. Strategic narratives are conceived of as stories with a political purpose or narratives used by political actors to affect the behavior of others. The articles in this issue address two significant areas important to the study of international relations: how strategic narratives support or undermine alliances, and how they affect norm formation and contestation. Within a post-Cold War world and in the midst of a changing media environment, strategic narratives affect how the world and its complex issues are understood. This special issue speaks to the difficulties associated with creating creative and committed international cooperation by noting how strategic narratives are working to shape the Post-Cold War international context.
\end{abstract}

\section{Keywords}

BRICS; genocide; intervention; narratives; politics; R2P; Russia; Ukraine; world order

Issue

This editorial is part of the issue "Narratives of Global Order", edited by Matthew Levinger (George Washington University, USA) and Laura Roselle (Elon University, USA).

(C) 2017 by the authors; licensee Cogitatio (Lisbon, Portugal). This article is licensed under a Creative Commons Attribution 4.0 International License (CC BY).

\section{Introduction}

For this issue of Politics and Governance, we issued an invitation to examine new strategic narratives for 21stcentury global challenges. As we noted in our call for papers, the contemporary world confronts civilizational challenges of unprecedented complexity, which can only be addressed through creative and committed international cooperation. Yet, twenty-five years after the end of the Cold War, governments and political movements around the globe are retreating into threadbare, exclusionary ethnic and nationalist narratives forged in the eighteenth and nineteenth centuries.

We defined strategic narrative as a story with a political purpose-often a story that can be crystallized into a single word or phrase, such as "containment", "democratization", or "the global war on terror". Such stories provide an organizing framework for collective action, defining a community's identity, its values and goals, and the stakes of its struggles. Interest in strategic narratives builds on the narrative turn in international relations that emphasizes the importance of narratives in shaping how international order is imagined and constructed, and the recognition that political actors attempt, under particular circumstances and in different ways, to shape the narratives through which sense is made of the international system, international relations, and policy. Most of the articles found here build on Miskimmon, O'Loughlin and Roselle's $(2013,2017)$ definition of strategic narrative.

We welcomed paper submissions on a range of methodological and thematic topics. We hoped to explore questions including:

- What are the linguistic, political, and institutional processes by which strategic narratives take shape? To what extent do narratives play a generative role in shaping strategic decisions, as opposed 
to reflecting other driving forces such as economic self-interest?

- What factors enable certain narratives to "stick" as organizing principles for strategic cooperation while others fail to translate into sustained cooperative action?

- Why, at the present historical moment, are divisive nationalist narratives more powerful than inclusive ones seeking to advance regional and global integration?

- What new narratives - and new strategies for collective action-might help improve international cooperation to address pressing challenges such as global climate change, nuclear proliferation, and the protection of vulnerable civilians from violence and humanitarian disasters?

The articles in this issue address the first three set of questions more robustly than the fourth. The papers chosen for inclusion address the dynamics of strategic narrative construction and their role in policymaking in alliances (Roselle, 2017), how Russian strategic narratives clash with Western European narratives of global order (Miskimmon \& O'Loughlin, 2017), what factors undermine BRICS strategic narrative (van Noort, 2017), how characteristics of genocide discourses shape strategic responses (Irvin-Erickson, 2017), and the implications of strategic narratives associated with "normalization" for decisions concerning international intervention or non-intervention in civil wars and transnational conflicts (Lemay-Hébert \& Visoka, 2017).

Strikingly, we did not receive any submissions that examined narrative strategies to enhance international cooperation or to address pressing global challenges. Indeed, the issue might be more aptly entitled "Narratives of Global Disorder" rather than "Narratives of Global Order", because the papers included here seek to understand narrative contestation and the sometimes unexamined effects of strategic narratives. This makes sense to us as the post-Cold War international system is in transition as is the communication technology ecology. Contestation is front and center.

\section{How Narratives Support or Undermine Alliances}

Laura Roselle's (2017) article analyzes how strategic narratives may foster or undermine cooperation in alliances. She examines Snyder's (1984) notion of an alliance security dilemma which suggests that fears of abandonment or entrapment shape alliance behavior in certain patterned ways and argues that strategic narratives play a central role in constructing these fears. Her essay focuses on two case studies of how US allies and adversaries have attempted "to use narratives to raise fears of abandonment and fears of entrapment designed to change the behavior of other actors": first, the adoption of UN Security Council Resolution 1973 of March 2011 calling for military intervention in Libya; and second, the Western alliance's imposition of punitive sanctions against Russia during the Ukraine crisis of 2014.

In the Libyan case, France and the UK attempted to persuade the US to cooperate in part by focusing on system and identity narratives that emphasized common values and the need to shape the international system. By situating the Libyan crisis within a "broader narrative of a liberal order in which states have responsibilities to individuals faced with authoritarian machinations", British and French leaders implied that "if the US did not go along, it would be outside the liberal order". Despite serious reservations about the wisdom of military intervention on the part of President Obama and most of his top advisers, the fear of being "left behind" by America's allies ultimately convinced Obama to authorize military action.

While the example of Libya shows how the use of strategic narratives can reinforce alliance cohesion by accentuating fears of abandonment, the Ukraine crisis illustrates the converse phenomenon: an adversary's deployment of narratives in order to undermine alliance cohesion by emphasizing the risks of entrapment. In the aftermath of Russia's annexation of Crimea in 2014, Russian President Vladimir Putin sought to challenge US authority in the international system and undermine Western sanctions efforts by refuting NATO's system and identity narratives. Putin argued that "in a post-bipolar world, the West, led by the US, acted selfishly, hypocritically, and without regard for international law". Putin's narratives found resonance in some Eastern European NATO member states, where political leaders opposed sanctions on Russia, arguing that "the US and NATO take advantage of those who are weaker" and calling for "the support of Christian values" as championed by Putin.

Alister Miskimmon and Ben O'Loughlin's (2017) essay probes in greater depth the "misalignment of narratives about world order projected by Russia and its Western interlocutors". Since the beginning of Putin's first presidency in 2000 , Russian leaders have consistently sought to counteract the Western unipolar system narrative that depicts the US as the "sole remaining superpower" with a narrative of a "polycentric world", in which Russia maintains great power status. According to this narrative, the Russian Federation must be recognized as a "centre of influence in today's world". In the words of Foreign Minister Sergey Lavrov, a "higher level of partnership" between Russia and the West "may be reached only on the basis of equality, mutual respect and consideration of each other's interests". This partnership requires "pragmatism", marked by an "understanding of our special responsibility for global stability", rather than "tormenting discussions about the search for general values".

Miskimmon and O'Loughlin (2017) make the thoughtprovoking claim that at this time of "rapid systemic change, the major point of debate" between Russia and its Western interlocutors "is the issue of recognition, rather than domination and redistribution". Instead of being recognized as a "co-constitutor" of the emerging 
Post-Cold War order in Europe, "since the early 1990s Russia has complained of being excluded from the major decisions affecting it", including the eastward enlargement of NATO and the European Union. The Kremlin's growing "frustration at this exclusion has triggered increasingly assertive action...to unilaterally defend what it perceives to be in its vital national interest". In the authors" view, "events in Ukraine are at least as much symptom as the cause of tension between Russia and the West", and an "underlying issue is a failure of Russia and the West to reach a common understanding of the international system".

Unfortunately, Miskimmon and O'Loughlin see little immediate prospect of alleviating the narrative misalignment between Russia and the West. American and European commentators, having previously dismissed Russia as a declining second-rank power, now breathlessly warn of a new Cold War against an "intransigent autocratic state"; and recent EU and NATO policy communiqués explicitly declare that "Russia is no longer a strategic partner". Russia, meanwhile, "feels mis-recognised, but articulates a vision of world order that appears unsuited to the dynamics of 21st-century power, shifting hierarchies and material conditions". This growing chasm between the rival strategic narratives "has driven a cycle of miscommunication, generating frustration on all sides and restricting the scope for cooperation".

The deterioration of relations between Russia and the West offers an illuminating example of how the failure to achieve narrative common ground can exacerbate international conflict by highlighting the disjuncture between the stories told by the rival sides. Carolijn van Noort's (2017) article on "Study of Strategic Narratives: The Case of BRICS" examines the converse phenomenon: the processes by which states with widely divergent power capabilities and strategic interests seek to build a collective identity and promote a new global order.

As van Noort (2017) points out, the nations of Brazil, Russia, India, and China-with the subsequent addition of South Africa-were "artificially grouped together in a famous Goldman Sachs working paper" identifying them as "large emerging market economies that had the potential to outperform the G7 countries". Yet, these nations embraced the idea of a BRICS bloc, with ministerial meetings in 2006 and the first BRIC Summit with heads of states in 2009.

This article traces the strategic narrative processes of the BRICS nations through analysis of joint communiqués and identifies a system narrative of global recovery, an identity narrative of inclusive participation, and an issue narrative of infrastructural development. An important addition to the literature on strategic narratives is van Noort's focus on the narrative environment of symbolic, institutional and material practices. Interestingly, the conclusion reached here is about the very mixed success of a unifying BRICS strategic narrative. What arguably undermines the coherence of this narrative is "that the coalition, and the NDB [New Development Bank] more specifically, are being shaped in ways that favor the interests and values of the two autocratic members" (Abdenur \& Folly, 2015, p. 88; Kiely, 2016, p. 33). The themes of good governance and development divide the issue narrative therefore into two camps: the "IBSA" countries (Brazil, India, South Africa) in the one camp, and Russia and China in the other.

\section{Narratives, Norm Formation, and Conflict}

While the first three articles in the issue examine how system and identity narratives can drive conflict or cooperation among states or groups of states, the final two essays explore how narratives about global norms are deployed to justify or resist demands for military intervention. Douglas Irvin-Erickson (2017) presents the concept of "genocide discourses"-a type of strategic narrative built on the principles that "the victims of genocide are necessarily moral innocents, not parties in conflict" and that "genocidal systems are dislodged only when they are swept away through external violence". These dual principles make genocide discourses "highly effective in conferring moral capital upon certain actors in a conflict". By casting "the perpetrators as evil" and "the victims as innocent", such narratives "prescribe external violence as the only means of defending the good".

Genocide discourses, writes Irvin-Erickson, can play a powerful role in "motivating humanitarian responses in defense of certain groups, or sustaining popular support for foreign wars". In their most extreme form, "a kind of reciprocal genocide becomes the imagined solution to genocide, insofar as the total annihilation of a supposedly evil social group is presented as the only way to prevent the total annihilation of a supposedly pure and innocent victim group". As case studies, IrvinErickson analyzes the dueling narratives of victimization told by Ukrainian and Russian leaders about the conflict between their countries, as well as the debates in the United States over Islamic State genocides in Iraq.

The final article in the special issue, by Nicolas LemayHébert and Gezim Visoka (2017), speaks to the consequences of particular strategic narratives as they argue that "the language of normalization, hidden behind...narratives of interventions, has...contributed to structure the intervention landscape". Normalcy and normalization within peace and conflict studies is used as "a normative goal of peacebuilding, as an intermediary measurement of success towards sustainable peace, or as a processual mechanism facilitating other postconflict processes". The authors suggest that normalization can be understood as a strategic narrative and that there are three modes of normalization: imposing normalcy, restoring normalcy, and accepting normalcy. These three are taken together as the concept of normal peace, "a new conceptual reference to understand interventions undertaken by the international community to impose, restore or accept normalcy in turbulent societies". 
Lemay-Hébert and Visoka (2017) argue that imposing normalcy can be seen as creating liberal subjects, and the measurement becomes state "performance"; restoring normalcy is set on building resilient subjects and a return to the status quo; and accepted normalcy "where international actors seek to manage risks through recognition of the plurality of ways of life". This seemingly abstract debate over definitions can have weighty political and military consequences: countries such as Bahrain and Saudi Arabia, which are judged by international policy elites to be "normal" despite engaging in "widespread torture and human rights abuses", are able to avoid punitive action. But other states such as Somalia or Afghanistan, which are deemed "abnormal", may be subjected to the deployment of international peacekeeping forces or even full-scale invasion. At heart the authors note the importance of understanding how knowledge production and strategic narratives shape the exercise of power on the global stage.

\section{Conclusion}

At a historical moment when the international system is in flux, the analysis of strategic narratives provides a productive lens for understanding this ongoing transformation. The articles in this issue illuminate the central role of storytelling in a wide range of decision-making processes in international affairs-from alliance formation to norm formation and conflict. Thus, these articles speak to the idea that narratives shape how international issues, and the international system itself, are understood.

The analysis of strategic narratives is critical for understanding certain processes (e.g. alliance formation) that are often taken for granted. Careful attention to narratives allows one to examine the underlying assumptions upon which behavior in the international system takes place. In a post-Cold War international system, narrative contestation is the focus of scholars as political actors seek to create an ordering principle within which alliances 'make sense', conflicts among nations are waged, and a 21st-century international order takes shape.

\section{Acknowledgements}

This special issue was supported by Elon University, the University of Birmingham, and George Mason University which provided funding for the publication of the articles. This institutional support allows for open access which benefits scholars and students throughout the world. We are grateful to the contributors and to the reviewers for their careful reading and suggestions. We are also very grateful to Rodrigo Gomes Quintas da Silva and the editorial team at Politics and Governance for their professionalism and support.

\section{Conflict of Interests}

The authors declare no conflict of interests.

\section{References}

Abdenur, A. E., \& Folly, M. (2015). The new development bank and the institutionalization of the BRICS. In J. Van den Bosch (Eds.), Beyond BRICS: New and rising global powers (pp. 66-95). Retrieved from http:// revjournal.org/wp-content/uploads/REV3/REVOLUT IONS_VOL.3.pdf

Irvin-Erickson, D. (2017). Genocide discourses: American and Russian strategic narratives of conflict in Iraq and Ukraine. Politics and Governance, 5(3), 130-145.

Kiely, R. (2016). The rise and fall of emerging powers: Globalisation, US power and the global north-south divide. Cham: Springer International Publishing.

Lemay-Hébert, N., \& Visoka, G. (2017). Normal peace: A new strategic narrative of intervention. Politics and Governance, 5(3), 146-156.

Miskimmon, A., \& O'Loughlin, B. (2017). Russia's narratives of global order: Great power legacies in a polycentric world. Politics and Governance, 5(3), 111-120.

Miskimmon, A., O'Loughlin, B., \& Roselle, L. (2013). Strategic narratives: Communication power and the new world order. New York, NY: Routledge.

Miskimmon, A., O'Loughlin, B., \& Roselle, L. (Eds.). (2017). Forging the world: Strategic narratives and international relations. Ann Arbor, MI: University of Michigan Press.

Roselle, L. (2017). Strategic narratives and alliances: The cases of intervention in Libya (2011) and economic sanctions against Russia (2014). Politics and Governance, 5(3), 99-110.

Snyder, G. H. (1984). The security dilemma in alliance politics. World Politics, 36(4), 461-495.

van Noort, C. (2017). Study of strategic narratives: The case of BRICS. Politics and Governance, 5(3), 121-129.

\section{About the Authors}

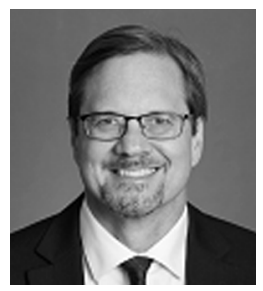

Matthew Levinger is Research Professor at George Washington University's Elliott School of International Affairs, where he directs the National Security Studies Program and the Master of International Policy and Practice Program. From 2004 to 2007, he was founding director of the Academy for Genocide Prevention at the United States Holocaust Memorial Museum. He received his PhD from the University of Chicago. 


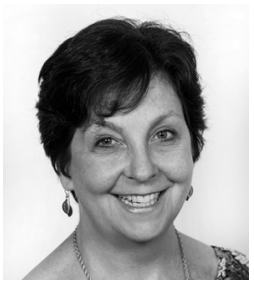

Laura Roselle is Professor of Political Science and Policy Studies at Elon University. She is the author of Media and the Politics of Failure (Palgrave, 2006 and 2011), and with co-authors Alister Miskimmon and Ben O'Loughlin, Strategic Narratives: Communication Power and the New World Order (Routledge, 2013) and Forging the World: Strategic Narratives \& International Relations (University of Michigan Press, 2017). Roselle is co-editor of the journal Media, War and Conflict, and co-editor of the book series, Routledge Studies in Global Information, Politics and Society. 